Journal of Economics and Behavioral Studies

Vol. 4, No. 6, pp. 376-383, June 2012 (ISSN: 2220-6140)

\title{
An Evaluation of the Emerging Teen Market in Durban, South Africa: Some Marketing Implications
}

\author{
Dayaneethie Veerasamy*, Natasha Robertson \\ Durban University of Technology, South Africa \\ *veerasamyd@dut.ac.za
}

\begin{abstract}
Children between the ages of eight and twelve, known as teenagers or teens, have become a lucrative customer base. These teens are considered to be 'in between' the traditional child and teenager stages of development. South African society has undergone a sweeping change in its vital institution-the family. Trends such as smaller family size, single parent households, dual incomes and postponing children until later in life means that society is increasingly becoming cash rich and time poor. Guilt plays a major contributing role in spending decisions as time-stressed parents substitute material goods for quality time spent with teens, therefore opening a floodgate to marketers who monopolize on this pang and guilt factor. Guilt consumerism has now transformed teens into key players in marketing strategies. This research paper aims to provide an insight into the rising consumerism in teens due to the 'nag' and 'pester' power- bug that has fuelled marketing tactics.
\end{abstract}

Keywords: Teenagers, teen market, nag and pester, guilt consumerism

\section{Introduction}

South Africa has entered a new era in marketing that is marked by the globalization of products and services (Brand preference research reveals a new youth culture in South Africa, 2004). Most of the marketing research thus far has focused on the adult consumers. However, South African marketers need to research the emerging teen market in order to get a better understanding of how teens develop into both consumers and influencers. A teen is a pre-pubescent between the ages of eight and twelve (McNeal, 1999). Lindstrom (2003) indicates that this generation has been tagged as the 'age of compression' since every aspect of todays teenager is different from the past generations of teenagers. These teens have grown up faster, are more connected because of digital technology, and are more direct and more informed. Therefore, they have more personal power, more money, influence and attention than the generation before them (Siegel, Coffey and Livingston, 2001).

The uniqueness of teens dictates that marketing research may be utilized in order to understand them and successfully market to them. Marketers still do not have a good understanding of how these teens think, and why they behave as they do in both the consumer and decision influencer role. South African marketers can no longer focus on messages that have a fixed position. There is a great need for 'diverse' marketing research among teens and this research paper aims to provide an insight into the rising consumerism among teens.

\section{Literature Review}

The past several decades has seen a trend towards teens playing a more active role in the family decisionmaking process and what the family buys. This has occurred as s result of couples has fewer children, more dual-income families, single parents encouraging greater household participation and self reliance and children being given the opportunity to express themselves (Schiffman and Kanuk, 2010). Teenagers today know exactly what they want and are wise and very aware of their surroundings. They are brand loyalists and empty promises will leave the marketer empty handed (Tinson and Nancarrow, 2007). Therefore, a brand's ability to 'speak' to these teens in their language will ensure loyalty. According to Lindstrom (2003), this teen generation has a greater impact on family spending than any other generation before them. Not only do they have substantial private discretionary income, but also they also exert tremendous influence on everyday family spending and long term decision-making (Tinson and Nancarrow, 2007). Marshall (2010) reports that 
teens are often involved in some aspect of family purchase decision making and it is thought that this involvement occurs at a younger age than in the past. Teens are involved in both simple impulse purchasing and in more planned purchases. In many cases, these teens may be the primary instigator, decision maker and shopper within the family. The degree of influence the child consumer has is likely to be related to the age of the child, parental attitudes towards advertising, the stage of decision making and the type of product (whether it is for the child's personal use or for the whole family). Today's teens are more independent and participate significantly in the purchasing decision-making of their families. These teens use "pester power" to nag their parents into purchasing items that they may not otherwise buy. Thus, marketing to these teens is all about creating pester power. Pestering or nagging can be divided into two categories - "persistence" and "importance." Persistence nagging is a plea, that is repeated repeatedly whilst "importance nagging." appeals to parents' desire to provide the best for their children, and plays on any guilt they may have about not having enough time for their kids. Veracity (2006) describes pester power as teens ability to ask or, actually, nag their parents for products with a good chance of having their wishes granted. Some teens have more pestered power than others have, and pester power takes many different forms. In addition, teens are able to quickly learn the pestering methods that work most effectively for their particular parents and then use them to the best of their advantage. Many working parents feel guilty about spending less time with their teens and start spending more money on them. Consequently, companies direct their advertising toward these teens because they could ask their parents for a product with a better chance of actually getting it. This parental guilt gives teens buying power. As misguided as this belief is, working parents often feel that their job schedules and household duties give them little alternative to showing their love through material goods and in effect, giving teens the benefits of "pester power."

In recent years, pester power has been one of the buzzwords of the international teen marketing industry. However, Tinson and Nancarrow (2007) believe that pester power is not merely a lifelong or even childhoodlong phenomenon since pestering teens grow quickly into purchasing adults. This 'pestering' change does not happen overnight, but poor information on just how and when this transformation takes place, combined with limited targeting options, and has made developing age-appropriate marketing strategies notoriously difficult. As a result, South African marketers have little choice but to use a blanket approach. Based on the 'pester power' principle, advertisers would have to aim almost solely at building brand awareness, rather than encouraging purchase (Soni and Upadhyaya, 2007). In a highly competitive marketplace, advertisers cannot afford to ignore opportunities to target their advertising more effectively. Lindstrom (2003) believes that brand relationships do not form in a vacuum. In light of this, marketers need to create strong attitudinal foundations before teens become truly brand loyal (Special Issues for Teens and Teens, 2008). More than just brand awareness, brand presence implies that the teen knows something about the brand promise, which is enough for them to accept or reject it. To offer an acceptance choice, a brand must avoid the negatives. Teens need to think that the brand will meet their basic needs by being in the right price range and 'fitting' with their self-image and values (Malerba, 2006). Teens are subjected to pressure from their peers and tend to follow the herd rather than their own instincts (Tinson and Nancarrow, 2007). This makes them less likely to develop a strong relationship with a single brand, unless it also appeals to their friends. Peer pressure diminishes as teens move from being a teenager to a teenager. The drop in peer pressure reflects the teen's rational and emotional development. As teens become more conscious of their image, so the basic function of a brand changes. Brands begin to be desired for their functional benefits as teens take a more active role in choosing their brands (Brand preference research reveals a new youth culture in South Africa, 2004). However, Lindstrom (2003) believes that teens may still not appreciate brands as a means of expressing a specific individual identity. Rather, he concludes that this age group often prefers one brand over another only because of their acceptance or popularity with more aspirational members of a peer group, or due to this linkage to activities of interest such as soccer and rugby. Although teens represent purchasing power in their own right, their influence on the product and brand spending of family members who hold the purse strings to disposable income, as well as their status as future adult consumers puts them high on the radar of marketers in product categories like clothing, electronics and mobile airtime (Leonardi 2007). Soni and Upadhyaya (2007) discovered that there is an ever-increasing exposure to teens in terms of technology and mass media. The major sweeping force behind this phenomenon is advertising, as advertising has, largely, changed the way teens learn, react and behave. Hymowitz (1998) believes that teens exhibit increasingly sophisticated tastes, especially in apparel and food and states that teens reject marketing messages that seem childish but are most heavily influenced by other teens and teens; but still often shop and buy with their 
parents as part of a family unit. The pang and guilt of not being able to spend quality time with teens is compensated by smothering them with material goods.

In reaching the teen market, Lindstrom (2003) recommends the following: Consider ethics - teens may have huge spending power and influence, but they are still kids. Establish presence among teens. Getting a brand known among teens is a critical first step and gives brand respectability, opening the door for it to be accepted by the group. Build a brand story teens believe in. Brands are popular, but to survive, brands will need to have opinions and attitudes. Put teens at the centre of any marketing program aimed at them. Build peer - to -peer marketing programs and develop viral marketing tools. Think mobile - teens are always on the move. Maximize mix of media channels - consider viral campaigns, the Internet, events, product placement and mobile phones instead of or as well as traditional media. Teens - that should be the new word doing the rounds in corporate boardrooms and marketing strategy meetings. The 8 to 12 year old, is still a child and not yet a teenager, but with awareness now about many adult issues and aspiring to a teenager lifestyle (The Financial Express 2007). In South Africa today, the teen is more aware, more informed, more demanding than ever before (Special Issues for Teens and Teens, 2008). Couple that with rising household incomes, and increased tendency to expiate parental guilt over not spending enough time with the teens by splurging on them, the teen market is booming and is expected to grow exponentially (Special Issues for Teens and Teens, 2008). Now that they are fast emerging as consumers, marketers can target the teen market in South Africa independently. The recent study undertaken, namely Special Issues for Teens and Teens (2008) clearly indicated that teens are also playing a major role in making brand purchase decisions for the households. As a result, marketers of diverse product categories need to find ways to capture attention of two very distinct audiences through one message. They must appeal to the adult purchaser, as well as to the teen who has the potential to influence that purchase.

\section{Methodology}

This research was quantitative, descriptive and cross sectional in nature. A convenience sample of 300 teenagers (children aged between eight and twelve years) across Durban, South Africa were given questionnaires to complete. A convenience sample of ten (10) primary schools was chosen; from which 30 respondents were randomly selected from each school. For the purpose of this study, judgmental sampling was used in the selection of respondents in terms of age (i.e. 8 to 12 years). These schools are representative of the broader socio-economic dispersion of the Durban population. The data collected was analyzed using computerized statistical analysis (i.e. SPSS program).

\section{Data Analysis: Respondents Information}

\begin{tabular}{cl}
\hline Total number of respondents $=300$ & Percentage (\%) \\
\hline Gender: Male & 55 \\
Female & 45 \\
Age: 10 Years & 35 \\
11 Years & 33 \\
12 Years & 32 \\
Allowance: Yes & 90 \\
No & 10 \\
\hline
\end{tabular}

Table 1 reveals that out of the sample of 300 teens, 165 were male and 135 were female. Their age category revealed the following: thirty five percent $(35 \%)$ of the respondents were in the ten-year age group whilst thirty three percent (33\%) were eleven years old. Thirty two percent (32\%) of the respondents were within the twelve-year age group. Table 1 further reveals that 75 out of the 300 respondents were in Grade 5 whilst 99 of the teen participants were in Grade 6. 126 respondents were in Grade 7. Ninety percent (90\%) of the teens received an allowance whilst ten percent (10\%) did not. Of the 270 teens who received an allowance, 189 received it monthly and 81 on a weekly basis. 
Breakdown of how allowance is spent: Figure 1 shows that forty five percent (45\%) of the teen respondents spent their allowance on mobile airtime, whilst thirty percent (30\%) of the participants spent their allowance on clothing. Thirteen percent (13\%) of the respondents spent their allowance on junk food, $8 \%$ on movies whilst a further four percent (4\%) dutifully spent their allowance on books and material for school. None of the respondents made allowances for transport cost and toiletries. This corresponds with (Leonardi, 2007) assertion that teens represent purchasing power in their own right, which puts them high on the radar of marketers in product categories like clothing, electronics and mobile airtime

Figure 1: Breakdown of Allowance

Books and /or material(s) for school

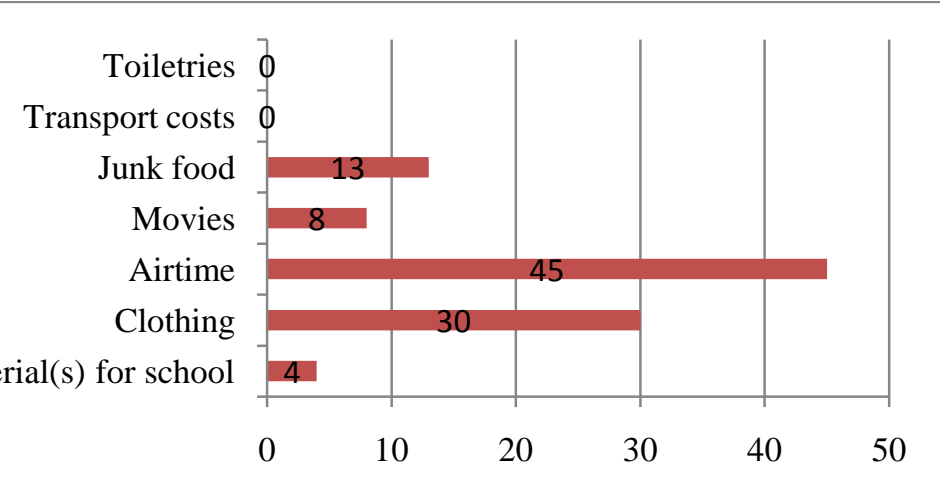

Figure 2: Internet access at home and/ or school

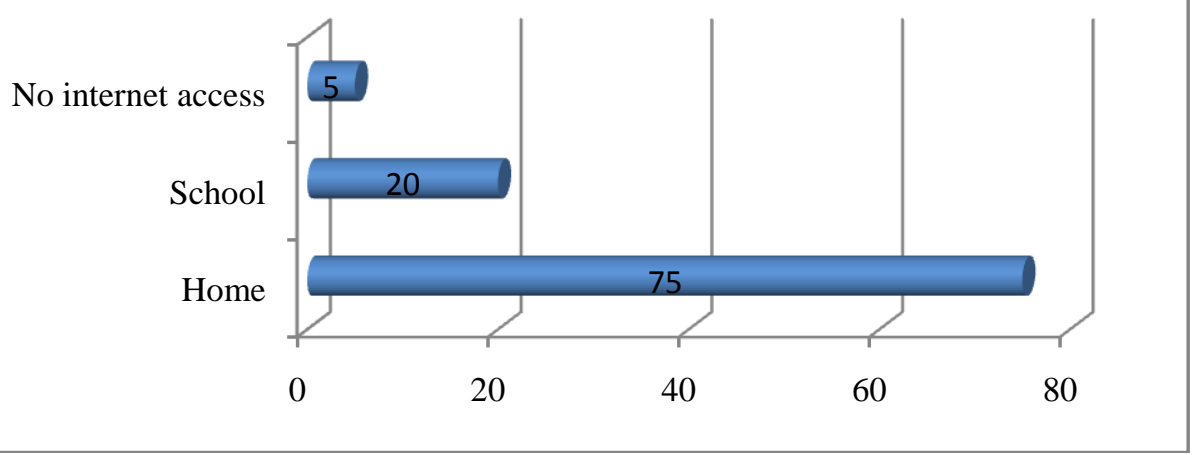

Internet Access: Figure 2 indicates that seventy five percent $(75 \%)$ of the teen participants indicated that they had internet access at home whilst twenty percent (20\%) of the respondents had access at school. Five percent (5\%) did not have any internet access at all. This supports Soni and Upadhyaya (2007) discovery that there is an ever-increasing exposure to teens in terms of technology and mass media.

\section{Figure 3: Internet Usage}

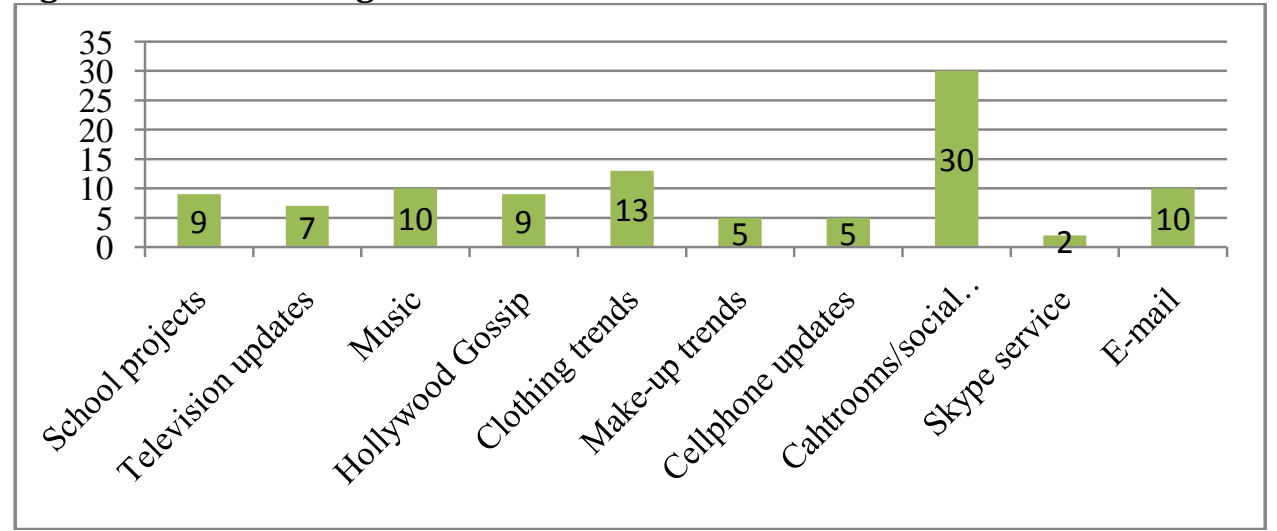


Internet usage: Figure 3 highlights that thirty percent (30\%) of the respondents used the internet for social networking and communicating via chat rooms. Ten percent $(10 \%)$ of the respondents used the internet for emailing purposes and a further thirteen percent (13\%) of the teen respondents surfed the internet for the latest fads and clothing trends. Ten percent $(10 \%)$ of the teen participants utilized the internet for listening to and/ or downloading music. Nine percent (9\%) admitted to surfing the internet for the latest Hollywood gossip and an additional nine percent (9\%) of the respondents dedicated their internet usage to school projects. Figure 3 also reveals that seven percent $(7 \%)$ of the teen participants surfed the internet for the latest television updates. An additional five percent (5\%) of the respondents viewed the latest make up trends on the internet whilst five percent (5\%) used the internet for cell phone updates. Only two percent $(2 \%)$ of the participants used the Skype service that is available on the internet.

Figure 4: Frequency of the internet

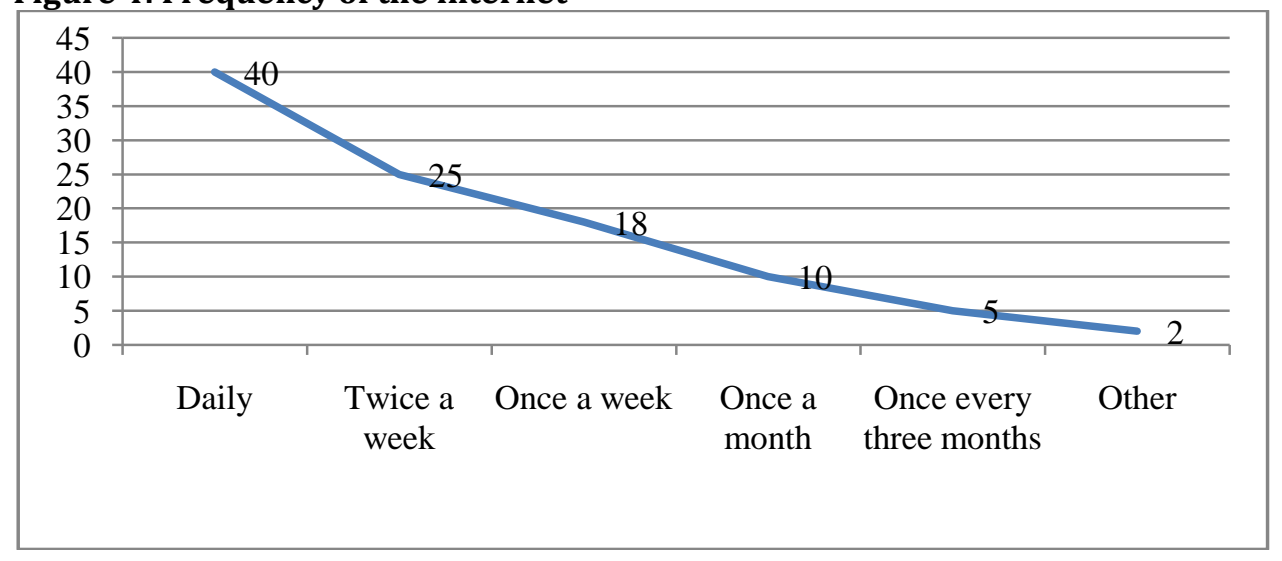

Frequency of use of internet by respondents: Figure 4 shows that forty percent $(40 \%)$ of the teen respondents used the internet on a daily basis whilst twenty five percent (25\%) of the participants surfed the internet twice a week. Eighteen percent (18\%) of the participants used the internet once a week only and an additional ten percent $(10 \%)$ of the sample accessed the internet monthly. Five percent $(5 \%)$ of the participants utilized the internet once every three months. Only two percent (2\%) of the respondents could not define how often they accessed the internet, therefore they were categorized under 'Other'. In essence, 249 of the 300 teens in this sample use the internet in any given week.

\section{Figure 5: Purchasing products over the internet (with permission)}

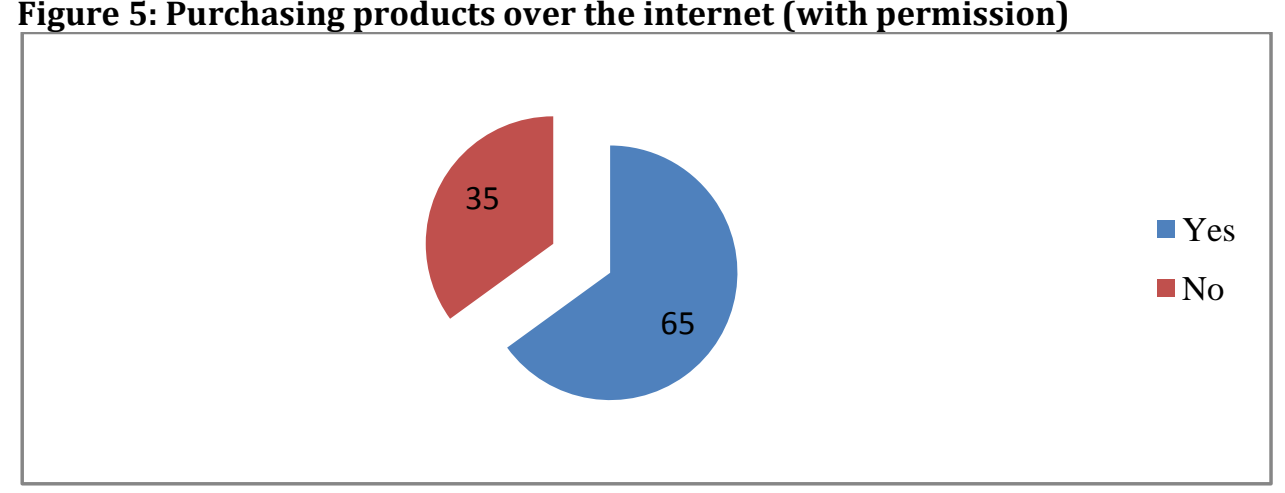

Purchasing products over the internet: Sixty five percent (65\%) of the respondents did not purchase any products over the internet whilst thirty five percent (35\%) of the teen, participants have purchased products over the internet with permission from their parents and/ or guardians as indicated by Figure 5. 105 of the 300-teen respondents have made independent purchases online. 
Figure 6: Friend influencing dressing habits

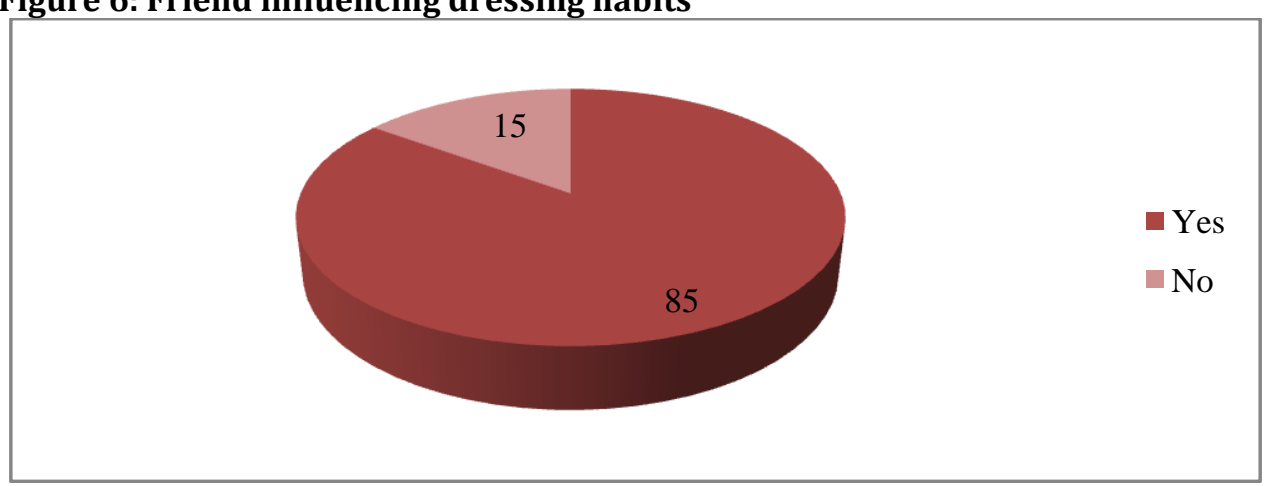

Influence the way teen's dress: Figure 6 reveals that eighty five percent (85\%) of the teen respondents are influenced by their friends, to dress in a particular way. On the other hand, fifteen percent $(15 \%)$ of the respondents stated that their friends did not influence the way they dress. Peer pressure is very prevalent as evidenced by 255 of the 300 -teen respondents indicating that they are influenced by their friends. This is consistent with Hymowitz (1998) belief that teens exhibit increasingly sophisticated tastes and is most heavily influenced by other teens and teens.

\section{Figure 7: Accompanying parents on shopping trips}

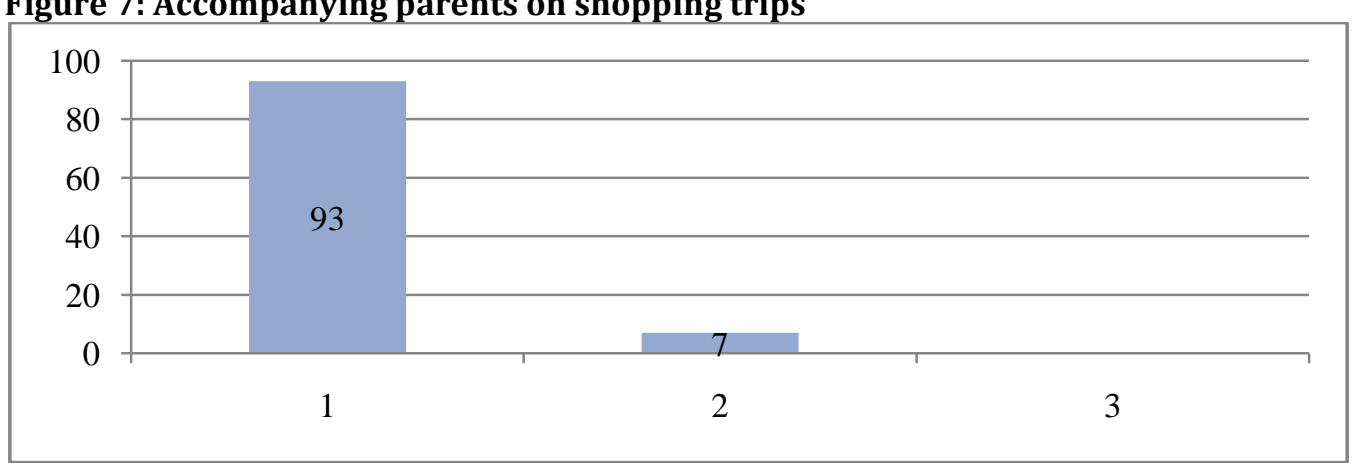

Accompanying parents on shopping trips: In Figure 7, ninety three percent (93\%) of the respondents stated that they did accompany their parents on shopping trips whilst seven percent (7\%) indicated that they did not accompany their parents on shopping trips. Since 279 of the 300 -teen respondents stated that they do accompany their parents on shopping trips, it can be assumed that they use the 'nag and pester' effect during these trips. This result concurs with Marshall's (2010) report that teens are often involved in some aspect of family purchase decision making and it is thought that this involvement occurs at a younger age than in the past. Teens are involved in both simple impulse purchasing and in more planned purchases. In many cases, these teens may be the primary instigator, decision maker and shopper within the family

\section{Figure 8: Parents/ guardian refuse to buy a particular item}

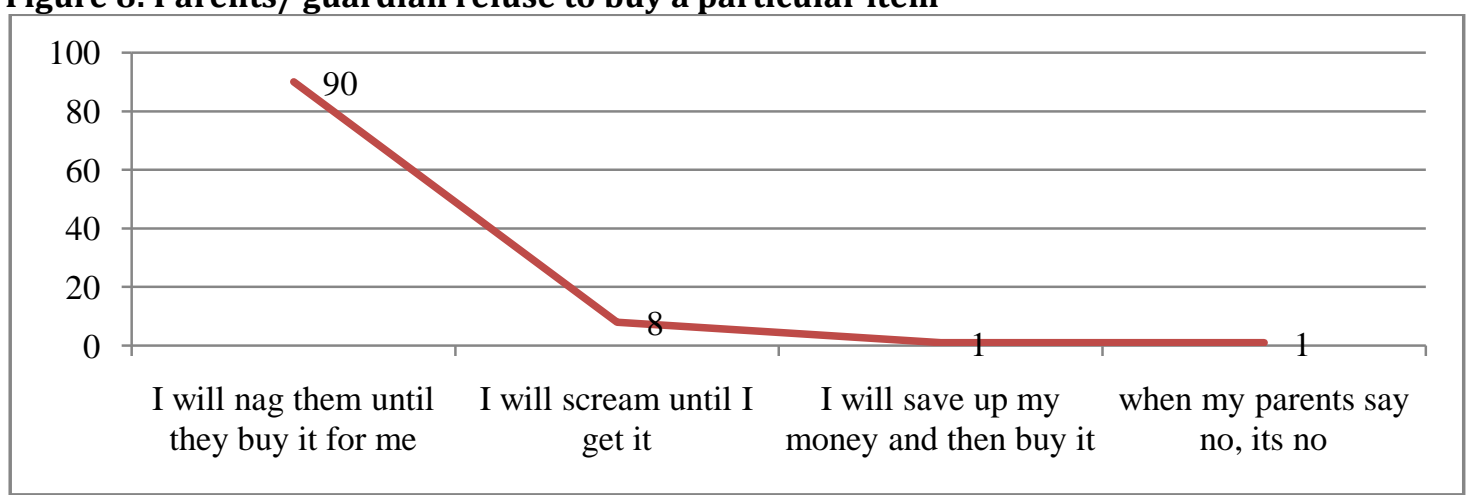


Parent(s)/ guardian refuse to buy a particular item: A majority of teens (90\%) stated that should their parent refuse to buy them a particular item, they would nag them (parent) until they (teen) received the item. The nag and pester power dominates as indicated by Figure 8. Veracity (2006) corroborates pester power as teens ability to ask or, actually, nag their parents for products with a good chance of having their wishes granted. Some teens have more pester power than others have, and pester power takes many different forms. In addition, teens are able to quickly learn the pestering methods that work most effectively for their particular parents and then use them to the best of their advantage. Many working parents feel guilty about spending less time with their teens and start spending more money on them. It is clear from the results above that teens have begun to be independent. Teens are old enough to form their own clear opinions about brands, can affect household decisions regarding shopping and brands, and are distinct enough as a marketing group to form a workable profile.

Marketing Implications: Given the context of this paper, the ecological validity limitations are acknowledged. Nonetheless, the following marketing implications can be considered. It is clear that the teens of today have more autonomy and decision-making power within the family so it follows that teens are more vocal about what they want their parents to buy. "Pester power" plays a huge role in a teen's ability to nag their parents into purchasing items they may not otherwise buy. Thus, marketing to South African teens is all about creating and maintaining this pester power, since advertisers now know what a powerful force it can be. Persistent nagging is not as effective as the more sophisticated "importance nagging." which appeals to parents' desire to provide the best for their teens, and plays on any guilt they may have about not having enough time for them. Marketers have an important role to play in that they can build the self-esteem of teens by communicating positive values and images in their communications directed at this target audience. To effectively reach the teen market, marketers need to have an integrated approach since no single medium can be identified to reach the South African teen market. However, teens do tend to spend a great deal of time and money on their mobile phones, the internet and social networking sites. Therefore, marketers may need to use these media to communicate with these teens.

Marketers need to consider using a mix of media channels to communicate with teens. These may include viral campaigns, the Internet, events, product placement and mobile phones instead of or as well as traditional media. Increasing accessibility to technology is enabling teens to play a more active role as consumers Targeted ads in the form of Internet marketing should be utilized on today's' teens. Marketers need to embrace this opportunity to design creative marketing campaigns that speak to this influential target audience, namely teens. The following untapped opportunities have been identified in the teen market:

As teens develop, approach and progress through puberty they are changing mentally, physically, emotionally, socially and spiritually. Teens exert considerable purchasing power influence by 'nagging' and 'pestering' third parents. Parental guilt also gives teens buying power. It is part of the youth culture today that teens are growing up with the Internet as a daily and routine part of their lives. Since these teens are technologically inclined, computers; the Internet; chat rooms; e-mail; Instant Messaging; cell phones and text messaging are, for the most part, staples for them. Therefore, the Internet is an extremely desirable medium for marketers wanting to target teens. In addition, technology makes it easy to collect information from young people for marketing research, and this assists with targeting individual teens with personalized advertising. Furthermore, by creating engaging, interactive environments based on products and brand names, companies have an opportunity to build brand loyalties from an early age.

\section{Conclusion}

To effectively market to children, advertisers need to analyze teen's behavior, fantasy lives; artwork; even their dreams and only then can these companies craft sophisticated marketing strategies to reach this burgeoning market. Marketers need to plant the seeds of brand recognition in today's' teens, in the hopes that the seeds will grow into lifetime relationships. Teens are altering the face of business and will do so well into the future therefore marketers have to consider how to capture the attention of two very distinct audiences in one message by appealing to the parents as well as the teen who influences them. 


\section{References}

Brand preference research reveals a new youth culture in South Africa (online). (2004). http://www.monash.ac.za/news/2005/Brand_preference_research_html.

Hymowitz, K. (1998). Teens: Ten going on sixteen (online). Available from: http://www.cityjournal.org/html8_4_al.htm

Leonardi, V. (2007). The Real Marketing Decision Makers - Selling to Children is far from Child's Play (online). Available from: http://www.brandsandbranding-online.co.za/the-real-marketing-decision-makersselling-to-children-is-far-from-child $\% \mathrm{E} 2 \% 80 \% 99$ s-play/

Lindstrom, M. (2003). Brandchild. London: Kogan Page Limited.

Malerba, F. (2006). Innovation and the evolution of Industries. Journal of Evolutionary Economics, 19(1), 323.

Marshall, D. (2010). Understanding children as consumers. Los Angeles: Sage

McNeal, J. (1999). Kids as Customers - a handbook of marketing to children. New York: Lexington Books.

Schiffman, L. G. \& Kanuk, L. L., (2010). Consumer Behavior. 10th Ed. Boston: Pearson

Shoham, A. \& Dalakas, V. (2006). How our adolescent children influence us as parents to yield to their purchase requests. Journal of Consumer Marketing, 23(6), 344-350.

Siegel, D. L., Coffey, T. J. \& Livingston, G. (2001). The great teen buying machine: Marketing to today's teens. New York: Paramount Market Publishing.

Soni, S. \& Upadhyaya, M. (2007). Pester Power Effect of Advertising. Paper delivered at the International Marketing Conference on Marketing and Society, Jaipuria Institute of Management, Jaipuria. 8-10 April 2007.

Special issues for Teens and Teens (online). (2008). Available from: http://www.mediaawareness.ca/english/parents/marketing/issues_teens_marketing.cfm.

The Teen Advantage. (online). (2007). Available from http://www.financialexpress.com/news/the-teenadvantage/200832/

Tinson, J. \& Nancarrow, C. (2007). Growing up: Teenagers involvement in family decision making. Journal of Consumer Marketing, 24(3), 160-170.

Veracity, D. (2006). Junk food, cereal and snacks increasingly marketed to children through pester power Available from http://www.naturalnews.com/019466.html\#ixzz1xkqgFZzD. 